\title{
AVALIAÇÃO DA PROTEINÚRIA RENAL EM GATOS SUPLEMENTADOS COM OMEGA 3 ASSOCIADO OU NÃO AO INIBIDOR DA ENZIMA CONVERSORA DE ANGIOTENSINA
}

\author{
(Evaluation of renal proteinuria in cats supplemented with omega 3 associated or not with the \\ angiotensin converting enzyme inhibitor)
}

Francielli Ambrosini, Simone Tostes de Oliveira Stedille, Marlos Gonçalves Sousa

Universidade Federal do Paraná, Curitiba, Paraná, Brasil.

*Correspondência: francielliambrosini@gmail.com

RESUMO: A doença renal crônica (DRC) é o distúrbio renal mais frequente na clínica médica de pequenos animais. Para o estadiamento, é necessário considerar sinais clínicos, histórico médico, exames laboratoriais, estudo de imagem e patologia renal (POLZIN, 2008). Sabe-se que os rins saudáveis possuem uma barreira seletiva e altamente especializada que impede a passagem de proteínas de alto peso molecular. Assim, a proteinúria de origem renal é um marcador de mau prognóstico da doença renal crônica, pois está associada à sua progressão. Através de métodos de mensuração da proteinúria pode-se avaliar o grau de lesão e acompanhamento dessa progressão. Lesões inflamatórias nas partes que compõem a barreira glomerular são responsáveis pela manutenção e progressão da mesma (HARALDSSON, NYSTRÖM e DEEN, 2008). Por esse motivo, o uso de antiinflamatórios, nesse caso o ômega 3 associado à controladores da pressão hidrostática glomerular, como inibidores da enzima conversora de angiotensina (enalapril), podem ser uma possibilidade de auxílio do tratamento da DRC. A avaliação desse efeito do omega 3 isolado ou em associação ainda não foi testado em gatos. Por esse motivo, teve-se por objetivo avaliar a proteinúria de gatos sob tratamento com ômega 3 associado ou não ao enalapril. Foram incluídos no estudo, até o momento, três gatos dentre 9 e 10 anos, com DRC e classificados de acordo com a International Renal Interest Society (IRIS) em IRIS II. Foram excluídos pacientes em síndrome urêmica, síndrome nefrótica ou aspectos clínicos que comprometessem a absorção dos fármacos ou impedissem seu uso, bem como o não comprometimento do tutor. Os animais receberam tratamento com ômega 3 (Organnact $\AA$ ) na dose de $1 \mathrm{ml} /$ gato durante 60 dias. Cada animal foi avaliado quanto à relação proteína/creatinina uirnária (RPC), pressão arterial sistólica e avalição clínica a cada 15 dias. No dia 30 associou-se $0,5 \mathrm{mg} / \mathrm{kg}$ de enalapril e as mesmas avaliações foram repetidas a cada 15 dias, totalizando cinco avaliações. Com utilização do software Minitab para análise estatística, realizou-se o teste de normalidade de Kolmogorov-Smirnov, teste T de Student ou teste $T$ pareado para comparação entre as médias das avaliações. Com 30 dias de uso de ômega 3, houve diminuição da proteinúria comparado ao dia zero $(p=0,035)$. Comparando $060^{\circ}$ dia de tratamento com o dia zero, também houve diminuição da RPC $(p=0,070)$. Não houve diferença comparando $\circ 30^{\circ}$ dia de tratamento com o $60^{\circ}$, ou seja, associar o enalapril a partir do dia 30, não promoveu maior redução se comparado apenas ao uso do ômega 3. Com esses resultados pode-se sugerir que somente $\mathrm{o}$ uso de ômega 3 tenha efeito antiinflamatório, por reduzir a proteinúria a partir de um mês de uso. A redução da proteinúria em gatos correlaciona-se com melhora do prognóstico e associar ômega 3 ao tratamento pode ser uma opção a ser considerada.

Palavras-chave: antiinflamatório; enalapril; doença renal crônica; relação proteína/creatinina urinária.

Nota: Projeto aprovado pela Comissão de Ética no Uso de Animais sob o protocolo número: 015/2019. 